\title{
Психофізичний та соціальний розвиток дітей молодшого шкільного віку в умовах спеціально організованої позашкільної рухової активності на основі занять карате
}

\author{
1Тетяна Петровська, ${ }^{2}$ Віталій Сергієнко,

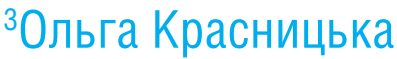

1Національний університет фрізичного виховання і спорту України, Київ,

Україна

²Диячо-юнацька спортивна школа «Сузір'я», Київ, Україна,

${ }_{3}^{3}$ Національний університет оборони України імені Івана Черняховського, Київ, Україна

\begin{abstract}
Анотація. Погіршення фрізичного та психічного здоров'я, складність соціалізації дітей молодшого шкільного віку внаслідок зменшення часу на фрізичне виховання у школі, переважну їх інтелектуальну зайнятість, систематичну роботу з гаджетами спонукають до організації позашкільної рухової активності, спрямованої на психофізичний та соціальний розвиток молодших школярів. Мета. Визначити особливості психофізичного й соціального розвитку дітей молодшого шкільного віку в умовах спеціально організованої позашкільної рухової активності на основі занять карате. Методи. Теоретичний аналіз, синтез та узагальнення наукових джерел, педагогічні, соціологічні, медико-біологічні методи, методи психодіагностики, методи математичної статистики. Результати. Розроблено програму психофізичного й соціального розвитку дітей молодшого шкільного віку в умовах спеціально організованої позашкільної рухової активності на основі занять карате, що містить шість блоків: пізнавальний, загальної фізичної підготовки, спеціальної фізичної підготовки, технічної підготовки, соціальнокомунікативний, тестування. Установлено позитивний вплив спеціально організованої позашкільної рухової активності на основі занять карате на показники психофізичного розвитку молодших школярів, зокрема функціональний стан серцево-судинної системи, фрізичну та розумову роботоздатність, фрізичну підготовленість, що проявляється в розвитку психомоторних якостей (сили, швидкості, гнучкості, витривалості, координації), зорової та слухової пам'яті, покращенні процесів переключення й розподілу уваги, збільшенні обсягу уваги. Доведено, що заняття карате сприяють соціальному розвитку, успішній соціалізації дітей і соціальній адаптації до нового соціального середовища. У процесі занять молодші школярі опановують нові соціальні ролі, норми та правила, формують соціальні якості й уміння, лідерські, морально-етичні якості та цінності, адекватну самооцінку, внутрішню позицію, навчаються встановлювати соціальні контакти й будувати взаємостосунки.

Ключові слова: молодші школярі, соціалізація, фрізична підготовленість, фрізична

роботоздатність, розумова працездатність, соціальні норми, ролі, якості.
\end{abstract}

Tetiana Petrovska, Vitalii Serhienko, Olha Krasnytska

PSYCHOPHYSICAL AND SOCIAL DEVELOPMENT OF PRIMARY

SCHOOL AGE CHILDREN IN THE SETTINGS OF SPECIALLY ORGANIZED EXTRACURRICULAR PHYSICAL ACTIVITY BASED ON KARATE CLASSES

Abstract. Deterioration of physical and mental health, difficulty of socialization of primary school age children due to reduced time for physical education at school, their predominant intellectual employment, and increasing use of gadgets encourage the organization of extracurricular
Petrovska T., Serhienko V., Krasnytska 0. Psychophysical and social development of primary school age children in the settings physical activity based on karate classes. Theory and Methods of Physical education and sports. 2021; 3: 96-103

DOI: 10.32652/tmfvs.2021.3.96-103 of specially organized extracurricular
Петровська Т., Сергієнко В., Красницька 0. Психосрізичний та соціальний розвиток дітей молодшого шкільного віку в умовах спеціально організованої позашкільної рухової активності на основі занять карате. Теорія і методика фрізичного виховання і спорту. 2021; 3: 96-103

DOI: 10.32652/tmfvs.2021.3.96-103
Вступ. Організація змістовного дозвілля дітей молодшого шкільного віку, зокрема позашкільної рухової активності, на сьогодні набуває все більшої актуальності. Це пов'язано зі стрімким погіршенням їхнього фрізичного та психічного здоров'я, складністю соціалізації. Адже негативні тенденції в організації фрізичного виховання в закладах загальної середньої освіти, зокрема зменшення кількості обов'язкових уроків на тиждень, зменшення часу на фрізичну активність, низька моторна щільність та інтенсивність навантажень, переважна зайнятість дітей у гуртках інтелектуального спрямування [1, 7], систематична робота 3 гаджетами призводять до ускладнень у психофізичному й соціальному розвитку. Н. Москаленко зазначає, що з початком навчання значно зростає обсяг розумової праці дітей і водночас відчутно обмежується їхня рухова активність [18]. А. Мелехов, І. Масляк у своєму дослідженні підтверджують зниження показників фізичної підготовленості молодших школярів, що проявляються в низьких показниках розвитку сили, швидкості, гнучкості, спритності та витривалості [15].

Молодший шкільний вік, як відомо, є сенситивним для психофрізичного й соціального розвитку дитини. Адже в цей час відбуваються зміни анатомо-срізіологічних, морфофрункціональних особливостей організму, розвиток психічно-пізнавальних процесів та властивостей, психофізичних якостей $[8,14]$. Після вступу до школи змінюються провідна діяльність, соціальна ситуація розвитку дитини, що впливають на процес її соціалізації. Зміна соціальної ролі, соціального середовища вимагає освоєння нових соціальних норм і правил, фрормування культури поведінки, соціальних умінь 
physical activity aimed at psychophysical and social development of primary school children. Objective. To determine the features of psychophysical and social development of primary school age children in the settings of specially organized extracurricular physical activity based on karate classes. Methods. Theoretical analysis, synthesis and generalization of scientific sources, pedagogical sociological, medical biological methods, psychodiagnostic methods, and mathematical statistics. Results. The program of psychophysical and social development of primary school age children in the settings of specially organized extracurricular physical activity based on karate classes was developed, which consisted of six blocks: educational, general physical training, specific physical training, technical training, social-communicative, testing. The positive effect of specially organized extracurricular physical activity based on karate classes was observed on the indicators of psychophysical development of primary school children, including the functional condition of the cardiovascular system, physical and mental working capacity, physical fitness in terms of development of psychomotor abilities (strength, speed, flexibility, endurance, and coordination), visual and auditory memory, improved processes of switching and distribution of attention, and increased amount of attention. The karate classes were found to contribute to social development, successful socialization, and social adaptation of children to a new social environment. During the classes, pupils mastered new social roles, norms, and rules developed social qualities and skills, leadership, moral and ethical qualities and values, adequate self-esteem, and inner attitude, learned to establish social contacts, and build relationships. Keywords: primary school children, socialization, physical fitness, physical working capacity, mental working capacity, social norms, roles, qualities.

та навичок [6, 25]. Саме організація змістовного дозвілля здатна забезпечити належні умови соціалізації дітей у вільний від навчання час $[5,13]$.

Рухова активність - невід'ємна частина способу життя та поведінки дітей молодшого шкільного віку. Як зауважує М. Бернштейн, вона є чи не єдиною формою життєдіяльності, шляхом якої організм молодшого школяра не просто взаємодіє з довкіллям, а й активно впливає на нього, змінюючи або прагнучи змінити його в потрібному йому відношенні [3]. ї̈̈ сприятливий вплив на здоров'я та розвиток дітей підтверджують О. Бар-Ор, Г. Бутенко, Г. Воскобойнікова, Н. Гончарова, С. Грицюк, І. Калиниченко, В. Кашуба, Т. Круцевич, Н. Москаленко, Н. Пангелова, Т. Роуланд, В. Рубан та багато інших учених.

Спеціально організована позашкільна рухова активність (СОПРА) $€$ одним із головних компонентів фрізичного виховання дітей молодшого шкільного віку [12] та організації їх змістовного дозвілля. Вона знаходить вираження в різних формах занять психомоторними вправами, гімнастикою, іграми й задовольняє біологічні, соціальні та особистісні потреби школярів.

СОПРА спрямована на зміцнення здоров'я дітей, підвищення їхньої фізичної роботоздатності, всесторонній та гармонійний розвиток, підвищення рівня психофізичного й соціального розвитку, формування здорового способу життя, успішність соціалізації особистості. Вона має соціальні цілі та виховну спрямованість [23]. Ї̈̈ забезпечують заняття в дитячо-юнацьких спортивних школах різноманітними видами спорту, наприклад, карате.

Карате розглядають як засіб не лише фрізичного розвитку, а й духовного, морального та соціального загалом, засіб пізнання себе та своїх можливостей, саморозвитку, пізнання духовних вершин, оскільки воно має міцну духовну основу. У процесі занять організм зміцнюється, гармонійно розвиваються всі його функціональні системи, швидкісно-силові та інші фрізичні якості, формується гарна статура. Різноманітність рухів обумовлює інтенсивне формування координаційних здібностей [16].

Заняття карате, як зазначає 3. Варфоломєєва, сприяють удосконаленню самоорганізації, психорегуляції, самовладання, культивуванню високих моральних якостей, підпорядкуванню тіла свідомості й волі [4].

Тренування у спортивних секціях дають змогу дітям молодшого шкільного віку опановувати нові соціальні ролі, розвивати соціальні вміння та якості, набувати соціального досвіду, досягати соціального статусу [19]. Вони легко задовольняють потребу в безпеці, соціальні потреби (спілкування, підтримка, прихильності), в повазі (однолітків, самоповазі, упевненості, досягнення), когнітивного рівня (пізнання та розуміння), за теорією
А. Маслоу. Таким чином, діти успішно проходять процес соціального становлення особистості, інтегруються в систему соціальних відносин, навчаються виражати своє «Я», розширюють межі соціалізації і закладають основи індивідуальності [11].

Під впливом тренувальних занять відбуваються зміни в опорноруховому апараті та інших системах організму, активніше розвивається м'язова система, зростає ї̈ рівень витривалості, збільшується сила дихальних м'язів, життєва ємність легень, покращується обмін речовин, підвищується рівень фізичної підготовленості, срізичної та розумової роботоздатності. Також в організмі виникає велика кількість умовно-рефлекторних зв'язків між корою головного м03ку, внутрішніми органами й руховим апаратом, що покращує діяльність центральної нервової системи, сприяє розвитку сприймання, мислення, уваги, пам'яті [21]

Незважаючи на значну кількість досліджень впливу занять організованою руховою активністю на психофізичний розвиток дітей молодшого шкільного віку, зазначимо, що вони здебільшого стосувалися окремих його аспектів, а саме психофізичних якостей, фрізичного стану, моторики, фрізичних здібностей, гармонізації фрізичного й розумового розвитку. Водночас зауважимо відсутність ґрунтовних досліджень соціального розвитку молодших школярів засобами фрізичного виховання та спорту, зокрема карате, що підтверджує актуальність нашого дослідження.

Мета дослідження - визначити особливості психофрізичного й соціального розвитку дітей молодшого шкільного віку в умовах спеціально організованої позашкільної рухової активності на основі занять карате.

Методи дослідження: теоретичний аналіз, синтез та узагальнення наукових джерел, педагогічний експеримент, анкетування, спостереження, педагогічне тестування, медико-біологічні методи (антропометричні вимірювання, фрізіологічні методи), методи психодіагностики (коректурна проба Анфімова, проєктивна методика 
Т а б л и ц я 1. Оцінювання показників фізичної підготовленості дітей молодшого шкільного віку (9-10 років) на констатуючому етапі педагогічного експерименту, $\mathrm{n}=257$, бал

\begin{tabular}{|c|c|c|c|c|c|c|}
\hline \multirow{3}{*}{ Показник } & \multicolumn{6}{|c|}{ Контингент обстежуваних } \\
\hline & \multicolumn{2}{|c|}{$\begin{array}{c}\text { Які займаються } \\
\text { у спортивних секціях } \\
(\mathrm{n}=97)\end{array}$} & \multicolumn{2}{|c|}{$\begin{array}{c}\text { У яких СОПРА має } \\
\text { оздоровчий характер } \\
(\mathrm{n}=28)\end{array}$} & \multicolumn{2}{|c|}{$\begin{array}{c}\text { У яких СОПРА } \\
\text { відсутня } \\
\text { (n=132) }\end{array}$} \\
\hline & Хлопчики & Дівчатка & Хлопчики & Дівчатка & Хлопчики & Дівчатка \\
\hline Сила & 5 & 5 & 2 & 5 & 2 & 3 \\
\hline Гнучкість & 3 & 4 & 2 & 2 & 2 & 2 \\
\hline Координація & 4 & 4 & 2 & 3 & 2 & 2 \\
\hline Швидкість & 4 & 5 & 3 & 3 & 2 & 2 \\
\hline $\begin{array}{l}\text { Рівень фізичної } \\
\text { підготовленості }\end{array}$ & добрий & добрий & $\begin{array}{l}\text { незадо- } \\
\text { вільний }\end{array}$ & $\begin{array}{l}\text { задо- } \\
\text { вільний }\end{array}$ & $\begin{array}{l}\text { незадо- } \\
\text { вільний }\end{array}$ & $\begin{array}{l}\text { незадо- } \\
\text { вільний }\end{array}$ \\
\hline
\end{tabular}

«Дерево»), методи математичної статистики.

Результати дослідження та їх обговорення. Дослідження проводили протягом 2016-2020 рр. на базі спеціалізованої школи I-III ступенів № 87 імені Олександра Довженка, середньої загальноосвітньої школи I-III ступенів № 126 та ДЮСШ «Сузір'я» м. Києва. У ньому взяли участь 257 молодших школярів 9-10 років та 17 класних керівників. Для проведення дослідження 3 дітьми молодшого шкільного віку було отримано письмову згоду їхніх батьків. Особливості психосрізичного та соціального розвитку молодших школярів в умовах спеціально організованої позашкільної рухової активності на основі занять карате визначено шляхом педагогічного експерименту.

На констатуючому його етапі найперше ми з'ясували особливості організації рухової активності учнів шляхом анкетування. Його результати дали змогу визначити інтереси й зайнятість дітей у позаурочний час, секції, які вони відвідують, кількість разів на тиждень. Згідно з отриманими даними, молодших школярів було розподілено на три групи: діти, у яких спеціально організована позашкільна рухова активність відсутня - 51,36 \% (132 особи, із них 58 хлопчиків і 74 дівчинки); діти, у яких спеціально організована позашкільна рухова активність має оздоровчий характер 10,9 \% (28 осіб, із них 14 хлопчиків і 14 дівчаток); діти, які займають- ся у спортивних секціях - 37,74 \% (97 осіб, із них 67 хлопчиків і 30 дівчаток).

За результатами анкетування було встановлено, що найбільшу перевагу діти віддають заняттям східними єдиноборствами (35,05 \% - 34 особи), 30 крема карате. Це спонукало нас у подальшому побудувати спеціально організовану позашкільну рухову активність молодших школярів на основі занять цим видом спорту.

Наступним кроком на констатуючому етапі педагогічного експерименту стало дослідження показників психосрізичного розвитку дітей молодшого шкільного віку. Аналіз соматометричних та фрізіометричних показників фізичного розвитку дав змогу встановити в цілому гармонійність їхнього фрізичного розвитку, відповідність віковим нормам. Проте, за даними індексу Кетле та індексу Робінсона, срізичний розвиток дітей знаходиться на рівні нижче середнього. Водночас важливим $€$ той аспект, що діти, які займаються у спортивних секціях, мають кращі показники, що характеризують розвиток м'язової системи й кісткового апарату та функціональний стан серцево-судинної системи.

У результаті аналізу фрізичної роботоздатності молодших школярів встановлено задовільний її рівень (63,8 \% хлопчиків та 56,8 \% дівчаток) у дітей, у яких спеціально організована позашкільна рухова активність відсутня. На противагу цьому діти, які займаються у спортивних секціях, показали середній рівень (70,1\% хлопчиків та 66,7 \% дівчаток). Водночас у цій групі спостерігався певний відсоток школярів із добрим та високим рівнями фрізичної роботоздатності. Діти, у яких спеціально організована позашкільна рухова активність має оздоровчий характер, продемонстрували добрий (42,9 \% хлопчиків), середній (42,9\% дівчаток) і задовільний (42,9 \% хлопчиків) рівні фрізичної роботоздатності.

Оцінювання фізичної підготовленості проводили шляхом тестування, зокрема виконанням таких вправ: підтягування на перекладині, згинання і розгинання рук в упорі лежачи, біг $30 \mathrm{~m}$, нахил із положення сидячи, човниковий біг $4 \times 9$ м, результати яких узагальнено в таблиці 1.

Наступним кроком на констатуючому етапі педагогічного експерименту стало оцінювання психічного розвитку дітей молодшого шкільного віку на основі анкетування класних керівників, результати якого подано на рисунку 1. Як бачимо, найнижчі показники мають молодші школярі, у яких спеціально організована позашкільна рухова активність відсутня.

У процесі аналізу результатів коректурної проби Анфімова з'ясовано рівні розумової працездатності дітей молодшого шкільного віку. Високий рівень зафріксовано у тих, хто займається у спортивних секціях $(65,7 \%$ хлопчиків та 70 \% дівчаток). Середній рівень продемонстрували $69 \%$ хлопчиків і 62,2 \% дівчаток, у яких спеціально організована позашкільна рухова активність відсутня, а також 64,3 \% хлопчиків та 57,1 \% дівчаток, у яких спеціально організована позашкільна рухова активність має оздоровчий характер.

Ще одним важливим кроком на цьому етапі педагогічного експерименту було вивчення особливостей соціального розвитку молодших школярів. З'ясовано, що діти, у яких спеціально організована позашкільна рухова активність відсутня, мають адекватну самооцінку (79,3 \% хлопчиків і $81,1 \%$ дівчаток), легко налагоджують соціальні контакти (51,7 \% хлопчиків та 63,5 \% дівчаток), дружні взаємостосунки в колективі однолітків (60,3 \% хлопчиків і 77 \% дівчаток), 
розвинені лідерські якості (13,8 \% хлопчиків та 14,9\% дівчаток), сфрормовану внутрішню позицію (39,7 \% хлопчиків і 45,9 \% дівчаток), ссрормовану мотивацію до навчальної діяльності $(51,7 \%$ хлопчиків та 47,3 \% дівчаток). Позашкільні інтереси мають 19 \% хлопчиків і 24,3 \% дівчаток (різноманітні гуртки), 3,4 \% хлопчиків та 5,4 \% дівчаток (конкурси, олімпіади).

Серед дітей, у яких спеціально організована позашкільна рухова активність має оздоровчий характер, адекватну самооцінку виявлено у 64,3\% осіб, легко налагоджують соціальні контакти 92,9 \% хлопчиків та 85,7\% дівчаток, дружні взаємостосунки в колективі однолітків мають 92,9 \% хлопчиків і 85,7 \% дівчаток, розвинені лідерські якості - 28,6 \% хлопчиків та 42,9 \% дівчаток, сорормовану внутрішню позицію - 71,4 \% хлопчиків і $78,6 \%$ дівчаток, сорормовану мотивацію до навчальної діяльності - 78,6 \% осіб. Позашкільні інтереси виявлено у 35,7 \% хлопчиків та 28,6 \% дівчаток (різноманітні гуртки), 21,4 \% хлопчиків і 35,7 \% дівчаток (конкурси, олімпіади).

Найвищі показники продемонстрували діти, які займаються у спортивних секціях. Серед них адекватну самооцінку мають 82,1 \% хлопчиків та 83,3 \% дівчаток, легко налагоджують соціальні контакти $91 \%$ хлопчиків і 90 \% дівчаток, дружні взаємостосунки в колективі однолітків - $97 \%$ хлопчиків та 96,7 \% дівчаток. Розвинені лідерські якості зафріксовано в 74,6 \% хлопчиків і 73,3 \% дівчаток, сфрормовану внутрішню позицію - 89,6 \% хлопчиків та 90 \% дівчаток, сформовану мотивацію до навчальної діяльності - 92,5 \% хлопчиків і 93 \% дівчаток. Позашкільні інтереси, крім занять спортом, спостерігаються у 22,4 \% хлопчиків та 33,3 \% дівчаток (різноманітні гуртки), 7,5 \% хлопчиків і 26,7 \% дівчаток (конкурси, олімпіади).

Отримані результати констатуючого етапу педагогічного експерименту засвідчили позитивний вплив занять спортом на психофрізичний та соціальний розвиток дітей молодшого шкільного віку, що проявляється у вищих їхніх показниках порівняно з дітьми, у яких спеціально організована позашкільна рухова активність відсутня або має оздоровчий характер. Це спонукало нас залучити до спеціально організованої позашкільної рухової активності, а саме занять у спортивній секції з карате, дітей, які мали низькі показники психофізичного й соціального розвитку. Таким чином було сфрормовано групу з 30 хлопчиків та 30 дівчаток.

На формувальному етапі педагогічного експерименту здійснено аналіз програм із карате, що реалізуються в ДЮСШ. З'ясовано, що всі вони переважно спрямовані на фізичний розвиток дітей. Виділено розділи загальної, спеціальної, технічної фрізичної підготовки. Дуже коротко подаються теоретичні знання про роль і місце карате в системі фрізичного виховання і спорту, його впливу на організм та особистість дитини. Однак, на наше переконання, виявлені особливості соціального розвитку молодших школярів спонукають до обов'язкового включення у програму занять 3 карате вправ, ігор, що сприятимуть розвитку їхньої інтелектуальної, комунікативної, емоційно-вольової, моральноетичної, поведінкової ссрер, забезпечуватимуть освоєння ними нових соціальних ролей, формування соціальної компетентності. у зв'язку з цим нами було розроблено та успішно впроваджено у тренувальний процес програму психофізичного й соціального розвитку дітей молодшого шкільного віку в умовах спеціально організованої позашкільної рухової активності на основі занять карате (табл. 2). Програма пройшла успішну апробацію на базі ДЮСШ «Сузір'я», підтвердженням чого стали результати контрольного етапу педагогічного експерименту. Тренувальні заняття 3 карате проводили тричі на тиждень.

На контрольному етапі педагогічного експерименту проведено повторне оцінювання показників психофізичного та соціального розвитку дітей молодшого шкільного віку, які були залучені до занять у спортивній секції 3 карате. Виявлено позитивні зміни в показниках фрізичної роботоздатності. Так, кількість хлопчиків, які мають задовільний їі рівень, зменшилася на 13,4 \%, а тих, які мають середній та добрий рівні, збільшилися на 10 і 3,4 \% відповідно. Більш значущі зміни зафіксовано під час оцінювання фрізичної роботоздатності дівчаток, серед яких не було виявлено тих, чий рівень оцінювався як задовільний. Натомість кількість дівчаток із середнім рівнем збільшилася на $20 \%$, із добрим - на $10 \%$.

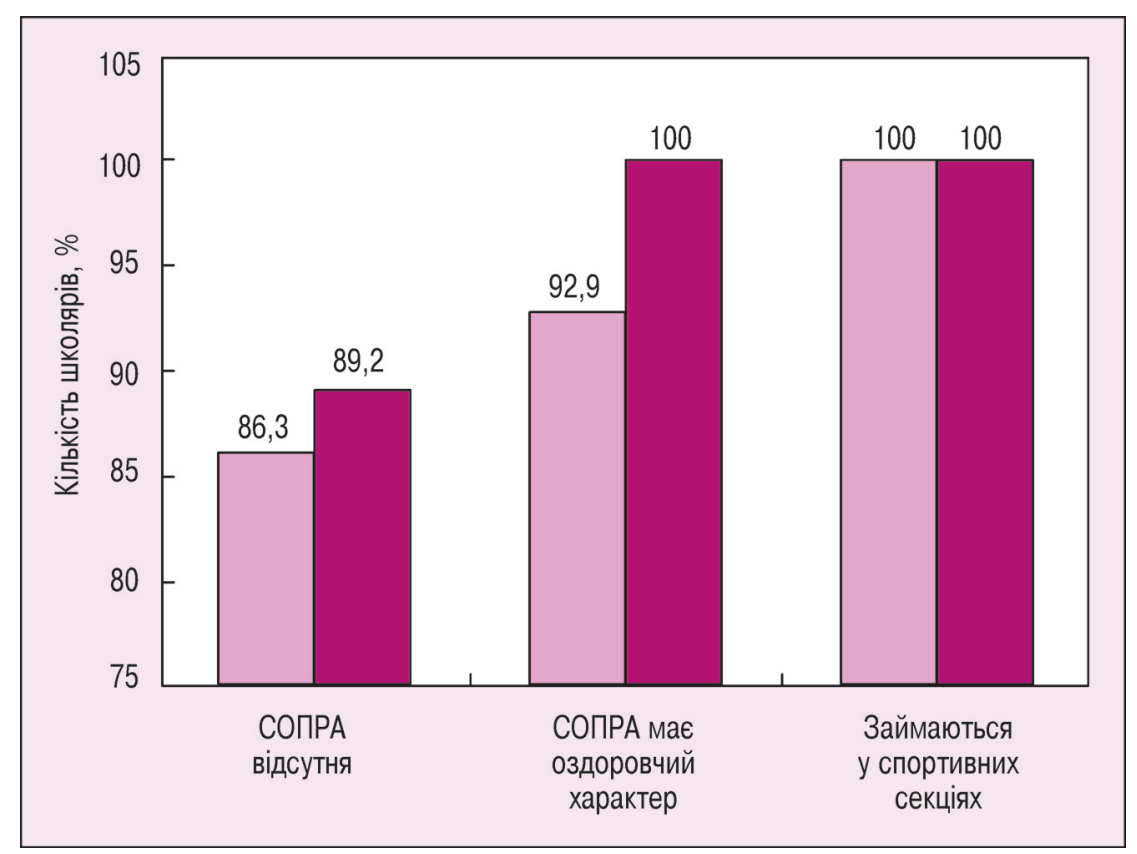

Рисунок 1 - Розподіл дітей за відповідністю психічного розвитку віковій нормі залежно від організації рухової активності, $\mathrm{n}=257$ :

- хлопчики; $\square$ - дівчатка 
Високий рівень фрізичної роботоздатності на контрольному етапі експерименту встановлено у 23,4 \% дівчаток, залучених до дослідження.

Оцінювання показників фрізичної підготовленості дітей молодшого шкільного віку (табл. 3) засвідчило статистично достовірне покращення $(p<0,05)$ рівня розвитку сили хлопчиків із незадовільного на добрий. Рівень розвитку їхніх гнучкості та швидкості піднявся за шкалою на одну сходину - 3 незадовільного на задовільний. Дівчатка продемонстрували підвищення розвитку швидкості з оцінки «незадовільно» на «добре», сили - 3 оцінки «задовільно» на «відмінно».

Результати проведення коректурної проби Анффімова (табл. 4) підтвердили позитивний вплив занять карате на показники розумовоїпрацездатності дітей молодшого шкільного віку. Так, показники обсягу інфрормації, що оброблялася хлопчиками, як на констатуючому, так і на контрольному етапах експерименту відповідали оцінці «добре». Водночас обсяг цієї інфрормації збільшився з 760,7 до 779,0 знаків, хоч і різниця між цими показниками не була статистично значущою ( $>$ > 0,05). Показники обсягу інформації, що підлягала опрацюванню дівчатками, відповідають оцінці «відмінно».

Для оцінювання соціального розвитку дітей молодшого шкільного віку ми використали проєктивну методику «Дерево». Згідно з отриманими даними, з'ясовано, що більшість хлопчиків $(43,3 \%)$ змінили установку на подолання перешкод. Лише 6,7 \% продемонстрували замкнутість, тривожність. Водночас 53,3 \% хлопчиків ототожнюють себе з позиціями, які характеризують товариськість, дружню підтримку, взаємовиручку. У 30 \% простежується мотивація на розваги, 3,3 \% школярів у процесі занять карате зайняли лідерську позицію, яка раніше їм взагалі була непритаманною.

Серед дівчаток 30 \% обрали позицію, спрямовану на подолання перешкод, 33,3 \% відзначили бажання досягати успіхів, але не переборюючи труднощі, й така сама кількість дівчаток відзначили мотивацію на розваги. Важливим показником стало те, що 73,3 \% школярок продемонстрували високу товариськість, взаємопідтримку, гордість за власні успіхи та успіхи своїх одноліток.
Т а б л и ц я 2. Структура програми психофізичного й соціального розвитку дітей молодшого шкільного віку в умовах спеціально організованої позашкільної рухової активності на основі занять карате

\begin{tabular}{|c|c|c|}
\hline Блок & Зміст заняття & $\begin{array}{l}\text { Кількість } \\
\text { годин }\end{array}$ \\
\hline \multirow{15}{*}{$\begin{array}{l}\text { Пізнавальний } \\
\text { (15 год) }\end{array}$} & Карате як система виховання людини & 1 \\
\hline & Правила безпеки під час занять карате & 1 \\
\hline & $\begin{array}{l}\text { Місце карате в системі бойових мистецтв світу. } \\
\text { Основні поняття карате }\end{array}$ & 1 \\
\hline & Здоровий спосіб життя - запорука міцного здоров'я & 1 \\
\hline & Оздоровчий аспект в системі бойових мистецтв & 1 \\
\hline & Джерела розвитку карате & 1 \\
\hline & Виникнення сучасного карате & 1 \\
\hline & Основні стилі та організації традиційного карате & 1 \\
\hline & Традиції та етикет в бойових мистецтвах & 1 \\
\hline & Тренер як наставник і майстер карате & 1 \\
\hline & $\begin{array}{l}\text { Ступені вдосконалення людини в карате. Поясна си- } \\
\text { стема оцінки }\end{array}$ & 1 \\
\hline & Організм людини - складна система & 1 \\
\hline & $\begin{array}{l}\text { Гігієна, режим загартовування, харчування } \\
\text { спортсменів }\end{array}$ & 1 \\
\hline & Видатні спортсмени-каратисти світу & 1 \\
\hline & Українські чемпіони з карате & 1 \\
\hline \multirow[t]{3}{*}{$\begin{array}{l}\text { Загальної фізичної } \\
\text { підготовки (24 год) }\end{array}$} & $\begin{array}{l}\text { Загальнорозвиваючі вправи з предметами та без } \\
\text { предметів }\end{array}$ & 9 \\
\hline & Різновиди ходьби, бігу & 5 \\
\hline & Рухливі ігри. Естафети & 10 \\
\hline \multirow{7}{*}{$\begin{array}{l}\text { Спеціальної фізичної } \\
\text { підготовки (54 год) }\end{array}$} & Вправи, спрямовані на розвиток сили & 5 \\
\hline & Вправи, спрямовані на розвиток гнучкості & 14 \\
\hline & Вправи, спрямовані на розвиток швидкості & 10 \\
\hline & Вправи, спрямовані на розвиток витривалості & 5 \\
\hline & $\begin{array}{l}\text { Вправи, спрямовані на розвиток координаційних } \\
\text { здібностей }\end{array}$ & 5 \\
\hline & Вправи, спрямовані на розвиток спритності & 5 \\
\hline & Рухливі ігри & 10 \\
\hline \multirow{6}{*}{$\begin{array}{l}\text { Технічний (технічної } \\
\text { підготовки) (60 год) }\end{array}$} & Базова техніка & 24 \\
\hline & $\begin{array}{l}\text { Техніка стійок (стійки готовності, навчальні стійки, } \\
\text { базові стійки) }\end{array}$ & 7 \\
\hline & Техніка пересування (крок, крок із поворотом) & 5 \\
\hline & Техніка ударів руками & 8 \\
\hline & Техніка ударів ногами & 8 \\
\hline & Техніка захисних дій & 8 \\
\hline
\end{tabular}


Продовження таблиці 2

\begin{tabular}{|c|c|c|}
\hline Блок & Зміст заняття & $\begin{array}{c}\text { Кількість } \\
\text { годин }\end{array}$ \\
\hline \multirow{6}{*}{$\begin{array}{l}\text { Соціально-комуні- } \\
\text { кативний (54 год) }\end{array}$} & Їгри, спрямовані на підвищення впевненості в собі & 10 \\
\hline & $\begin{array}{l}\text { Їгри, спрямовані на розвиток уяви та } \\
\text { спостережливості, уважності, контролю }\end{array}$ & 10 \\
\hline & $\begin{array}{l}\text { Іігри, спрямовані на розвиток командного духу, } \\
\text { згуртованості }\end{array}$ & 10 \\
\hline & Іігри, спрямовані на розвиток емоційної сфери & 10 \\
\hline & Їгри, спрямовані на розвиток комунікативних умінь & 10 \\
\hline & Вправи на релаксацію & 4 \\
\hline \multirow[t]{4}{*}{ Тестування (9 год) } & Участь у змаганнях & - \\
\hline & $\begin{array}{l}\text { Оцінка фізичної підготовленості, фізичної } \\
\text { працездатності }\end{array}$ & 3 \\
\hline & Оцінка показників психофізичного розвитку & 3 \\
\hline & Оцінка показників соціального розвитку & 3 \\
\hline Усьогогодин & & 216 \\
\hline
\end{tabular}

Отримані дані у процесі педагогічного експерименту переконливо доводять позитивний вплив спеціально організованої позашкільної рухової активності на психосрізичний та соціальний розвиток дітей молодшого шкільного віку. Результати експерименту засвідчили, що діти, які займаються у спортивних секціях, мають вищі показники функціонального стану серцево-судинної системи, фрізичної підготовленості, фрізичної та розумової роботоздатності. Натомість показники дітей, у яких спеціально організована позашкільна рухова активність відсутня, свідчать про їх низьку адаптованість до фрізичних навантажень, підвищену втомлюваність і швидкість її настання, що негативно позначається на навчальній діяльності.

Незважаючи на те що в більшості молодших школярів установлено відповідність психічного розвитку віковій нормі, усе таки рівень переключення й розподілу уваги, обсяг уваги, зорова та слухова пам'ять відповідають середньому рівню в дітей, у яких спеціально організована позашкільна рухова активність має оздоровчий характер, і низькому рівню - у тих, у кого СОПРА відсутня. Натомість високий рівень демонструють школярі, які займаються у спортивних секціях. Ці показники знаходяться у прямому взаєм0зв'язку 3 відповідними рівнями розумової працездатності: чим він вищий, тим вищий рівень стійкості та концентрації уваги, що безпосередньо впливає на якість сприйняття й засвоєння матеріалу у процесі навчання.

Соціальний розвиток дітей молодшого шкільного віку протікає у процесі соціалізації й пов'язаний зі зміною соціального середовища, провідної діяльності, розширенням кола соціальних контактів, новими соціальними відносинами, появою нових значущих дорослих, побудовою взаємостосунків у шкільному середовищі $[10,24]$.

Результати дослідження довели, що заняття у спортивних секціях, зокрема карате, сприяють фрормуванню в дітей адекватної самооцінки, активності у спілкуванні, навчають установлювати соціальні контакти, взаємодіяти один з одним та в команді, виховують лідерські якості, прагнення до перемоги, допомоги один одному, відповідальність не лише за себе, а й за команду.

Розвинути зазначені якості в молодших школярів ми змогли через із карате різноманітних ігор, що знайшли відображення у блоках загальної та спеціальної фрізичної підготовки, соціально-комунікативному блоці програми психофрізичного й соціального розвитку. Вважаємо виправданою включення у тренувальний процес думку Є. Ільїна, що гра в молодшому шкільному віці є видом інтелектуальної, емоційної та фрізичної активності, а також способом задовольнити вроджену потребу дитини в забавах, розвагах [9], що підтверджують показники дітей щодо мотивації до розваг.

Отримані нами позитивні зрушення у процесі соціального розвитку й соціалізації молодших школярів підтвердили результати досліджень В. Бельца та Ю. Ревякина [2], А. Москаленко, Т. Дорофєєвої [17], А. Попової [20], В. Саєнко і С. Скляра [22], у психофрізичному розвитку - наукових розвідок В. Мікрюкова [16].

Позитивна динаміка показників психофізичного й соціального розвитку дітей молодшого шкільного віку засвідчує позитивний вплив спеціально організованої позашкільної рухової активності на основі занять карате на їх фрізичне та психічне здоров'я і соціалізацію, а також підтверджує ефективність розробленої програми.

Висновки. Карате $є$ одним із видів спеціально організованої позашкільної рухової активності, що сприяє психосрізичному й соціальному розвитку дітей молодшого шкільного віку, успішній соціалізації, соціальній адаптації, формуванню соціально значущих особистісних якостей та властивостей у процесі спільного виконання психомоторних вправ.

Заняття карате розширюють світогляд дітей, формують нові знання та вміння, духовний світ школяра, внутрішню позицію, адекватну самооцінку, установку на лідерство, позитивне ставлення до себе та навколишніх, товариськість і дружню підтримку в міжособистісних стосунках, систему морально-етичних цінностей, естетику дії, мотивацію досягнень та мотивацію на успіх. У процесі тренувальних занять діти засвоюють нові соціальні ролі, норми та правила, навчаються взаємодіяти в команді. Здорова конкуренція фрормуе емоційно-вольові якості, моральноетичні цінності, командний дух, сприяе досягненню соціального статусу.

Заняття карате комплексно впливають на організм молодшого школяра, його психомоторні та духовні властивості, розвивають силу, швидкість, гнучкість, координаційні здібності, витривалість, а також уважність, мислення, кмітливість, швидкість реакції, до- 
Т а б л и ц я 3. Показники фрізичної підготовленості дітей молодшого шкільного віку (9-10 років) на констатуючому та контрольному етапах експерименту

\begin{tabular}{|c|c|c|c|c|c|c|c|c|}
\hline \multirow{3}{*}{ Показник } & \multicolumn{4}{|c|}{ Хлопчики (n = 30) } & \multicolumn{4}{|c|}{ Дівчатка $(n=30)$} \\
\hline & \multicolumn{2}{|c|}{ Констатуючий етап } & \multicolumn{2}{|c|}{ Контрольний етап } & \multicolumn{2}{|c|}{ Констатуючий етап } & \multicolumn{2}{|c|}{ Контрольний етап } \\
\hline & $x$ & S & $x$ & S & $x$ & $S$ & $x$ & $\$$ \\
\hline Підтягування на перекладині, разів & 3,20 & 1,13 & $5,93^{*}$ & 1,05 & - & - & - & - \\
\hline Згинання і розгинання рук в упорі лежачи, разів & - & - & - & - & 8,07 & 3,95 & 12,93 & 4,40 \\
\hline Нахил з положення сидячи, см & 2,57 & 1,72 & 4,00 & 1,49 & 4,20 & 1,47 & $9,07^{\star}$ & 1,74 \\
\hline Човниковий біг 4 ×9 м, с & 13,81 & 0,34 & 13,52 & 0,27 & 13,53 & 0,25 & 13,19 & 0,29 \\
\hline Біг 30 м, c & 6,91 & 0,27 & 6,60 & 0,29 & 6,92 & 0,19 & 6,64 & 0,17 \\
\hline
\end{tabular}

Примітка. * - різниця статистично достовірна порівняно з попереднім етапом дослідження при $p<0,05$

Т а б л и ц я 4. Показники розумової працездатності дітей молодшого шкільного віку (9-10 років) на констатуючому та контрольному етапах експерименту

\begin{tabular}{|c|c|c|c|c|c|c|c|c|}
\hline \multirow{3}{*}{ Показник } & \multicolumn{4}{|c|}{ Хлопчики $(\mathrm{n}=30)$} & \multicolumn{4}{|c|}{ Дівчатка $(n=30)$} \\
\hline & \multicolumn{2}{|c|}{ Констатуючий етап } & \multicolumn{2}{|c|}{ Контрольний етап } & \multicolumn{2}{|c|}{ Констатуючий етап } & \multicolumn{2}{|c|}{ Контрольний етаг } \\
\hline & $x$ & s & $x$ & s & $x$ & s & $x$ & s \\
\hline Обсяг обробленої інформації, знаків & 760,7 & 12,9 & 779,0 & 13,0 & 805,4 & 11,3 & 817,0 & 12,1 \\
\hline Загальні помилки, знаків & 5,3 & 0,5 & 5,3 & 0,5 & 4,3 & 0,5 & 3,2 & 0,4 \\
\hline $\begin{array}{l}\text { Коефіцієнт розумової працездатності, } \\
\text { ум. од. }\end{array}$ & 661,8 & 11,2 & 677,7 & 11,3 & 724,8 & 10,5 & 727,1 & 10,7 \\
\hline
\end{tabular}

тепність, ініціативність, силу волі, підвищують рівень фрізичної підготовленості, срізичної та розумової роботоздатності.

Зафіксовані показники психофізичного й соціального розвитку молодших школярів підтверджують необхідність організації змістовного дозвілля дітей, зокрема позашкільної рухової активності під керівництвом фрахівців із фрізичної культури та спорту.

Перспективи подальших досліджень полягають у вивченні психофрізичного та соціального розвитку дітей підліткового віку, особливостей їх соціалізації у процесі занять спортом, a також можливостей впровадження програми психофізичного й соціального розвитку дітей на основі занять карате у процес фрізичного виховання школярів основної школи.

Конфлікт інтересів. Автори заявляють, що відсутній будь-який конфрлікт інтересів.

\section{ЛІТЕРАТУРА}

1. Андрєєва 0, Чернявський М. Оцінка доцільності впровадження рекреаційно-оздо- ровчих технологій в процес фрізичного вихо вання молодших школярів. Спортивний вісник Придніпров'я. 2009;2-3:17-9.

2. Бельц ВЭ, Ревякин ЮТ. Восточные еди ноборства как средство социализации детей в учреждениях дополнительного образования: монография. Томск: изд-во ТГАСУ; 2015. 200 с.

3. Бернштейн НА. Очерки по фризиологии движений и физиологии активности. Москва: Медицина; 1966. 349 с

4. Варфоломеева 3С, Ямковенко АВ, Чирков ВС. Занятия каратэ как средство социализации детей и подростков [Інтернет] http://gisap. eu/ru/node/4256.

5. Ващенко ОМ, Єрмолова ВМ, Іванова ЛІ. Фізкультурно-оздоровчі заклади в режимі навчального дня молодшого школяра: навч. метод. посібник. Кам'янець-Подільський: Абет ка; 2003. 192 с.

6. Герлянд ТМ. Соціальний розвиток мо лодших школярів у групах подовженого дня [авторефрерат]. Київ: Інститут проблем виховання АПН України; 2007. 18 с.

7. Дикий ОЮ. Сучасні підходи до організаціі фізичного виховання школярів. Педагогічний пошук. 2019;1(101):24-28.

8. Дуткевич ТВ. Дитяча психологія: навч. посібник. Київ: Центр учбової літератури; 2012. $424 \mathrm{c}$.

9. Ильин ЕП. Психология для педагогов Санкт-Петербург: Питер; 2012. 640 с.

10. Кравченко ТВ. Теоретико-методичні засади соціалізації дітей шкільного віку у взаємодії сім'ї і школи [авторесрерат]. Київ: Інститут проблем виховання НАПН України; 2010. 40 с.
11. Красницкая ОВ. Социальное становление воспитанников интернатных заведений спортивного просииля. Специалист XXI века: Психологопедагогическая культура и профессиональная компетентность. Сборник материалов V Междунар. науч.-практ. конф., 2016 Окт. 20-22; Барановичи. Барановичи: БарГУ; 2016:61-3.

12. Круцевич ТЮ. Теорія і методика фрізичного виховання: підручник. Київ: Олімпійська л-ра; 2017. Т. 2. Методика фрізичного виховання різних груп населення. 368 с

13. Лука К. Специфіка соціалізації молодших школярів у закладах позашкільної освіти. В: Фролов М, редактор. Молода наука-2015. Зб. наук. праць студентів, аспірантів і молодих вчених; 2015 Квіт. 7-9; Запоріжжя. Запоріжжя: Запорізький національний університет; 2015: 329-330.

14. Мандель БР. Возрастная психология: учеб. пособие. Москва: Вузовский учебник: ИНФРА-М; 2015. 352 c.

15. Мелехов АВ, Масляк ІП. Фізична підготовленість дітей молодшого шкільного віку. Актуальні проблеми фізичного виховання різних верств населення: зб. наук. праць; 2018:179_ 185 [Інтернет]. Доступно: http://journals.uran.ua/ hdafk-tmfv/article/view/167214.

16. Микрюков ВЮ. Энциклопедия каратэ. 2018 [Інтернет]. Доступно: https://sport. wikireading.ru/16677

17. Москаленко А, Дорофєєва Т. Підвищення рівня фізичної підготовленості дітей молодшого шкільного віку шляхом комплексної спортивно-ігрової організації занять з фізичної культури. Проблеми і перспективи розвитку спортивних ігор і єдиноборств у вищих навчальних закладах. 2018;2:48-54. 
18. Москаленко НВ. Фізичне виховання молодших школярів: монографія. 3-є вид., перероб та доп. Дніпропетровськ: Інновація; 2014. 375 с.

19. Петровська Т, Імас $€$, Сергієнко В. Модель позашкільних занять карате, спрямована на психофізичний та соціальний розвиток дітей молодшого шкільного віку. Теорія і методика фріз. виховання і спорту. 2018;2:83-8. https://doi. org/10.32652/tmfvs.2018.2.83-88.

20. Попова АА. Успешность как продукт социализации обучающегося в карате. Роль инноваций в транссормации современной науки Сборник статей Междунар. науч.-практ. конф. 2016 Июль 01; Уфа. Уфа; 2016:274-6.

21. Присажнюк CI, Оленєв ДГ. Курс лекцій 3 фізичного виховання [Інтернет]. Доступно: https://pidru4niki.com/92480/pedagogika/biologichni_osnovi_fizichnogo_rozvitku_organizmu_ lyudini.

22. Саєнко ВГ, Скляр МС. Позитивний вплив на дітей тренувальних занять 3 карате 2012 [Інтернет]. Доступно: https://www.researchgate. net/publication/311536397.

23. Сергієнко В. Еволюційний поступ спеціально організованої позашкільної рухово активності як особливого різновиду всебічного розвитку молодших школярів. Спортивна наука України. 2018;2(84):36-9.

24. Човган РЯ. Розвиток соціальної активності школярів 10-11 років засобами фізично культури в умовах дитячого оздоровчого табору [авторефрерат]. Івано-Франківськ: ДВНЗ «При карпатський національний університет ім. Василя Стефаника»; 2016. 18 с.

25. Geisler TM. Examining The Socialization Of Physical Education Teachers: A Case Study; 2017. 725 p.

\section{LITERATURE}

1. Andrieieva 0 , Cherniavskyi M. Assessment of the feasibility of introducing recreational and health-enhancing technologies in the process of physical education for primary school children. Sportyvnyi visnyk Prydniprovia. 2009;2-3:17-9.

2. Belts VE, Revyakin YuT. Martial arts as a means of children's socialization in institutions of additional education: monograph. Tomsk: publ. house of Tomsk State University of Architecture and Building; 2015. 200 p.

3. Bernshtein NA. Essays on the physiology of movements and the physiology of activity. Moscow: Meditsina; 1966. 349 p.

4. Varfolomeeva ZS, Yamkovanko AV, Chirkov VS. Karate classes as a means of children's socialization. [Internet]. http://gisap.eu/ru/node/4256.

5. Vashchenko OM, Yermolova VM, Ivanova LI. Sports and health-enhancing facilities in the daily educational routine of primary school children: educ.-method. manual. Kamianets-Podilskyi: Abetka; 2003. 192 p.

6. Gerliand TM. Social development of primary school children in extended day groups [avtoreferat]. Kyiv: Institute of Problems on Education of the Academy of Pedagogical Sciences of Ukraine; 2007; 18 p

7. Dykyi OYu. Modern approaches to the organization of physical education of school students. Pedagogichnyi poshuk. 2019;1(101):24-28.

8. Dutkevych TV. Children's psychology: study guide. Kyiv: Center for Educational Literature; 2012. 424 p.

9. Iliin EP. Psychology for pedogogues. Saint Petersburg: Piter; 2012. 640 p.
10. Kravchenko TV. Theoretical and me thodological principles of socialization of schoolage children through the interaction of family and school [avtoreferat]. Kyiv: Institute of Problems on Education of the Academy of Pedagogical Sciences of Ukraine; 2010; $40 \mathrm{p}$

11. Krasnitskaya OV. Social development of students of boarding schools of a sports profile. Professional of the 21st century: Psychological and pedagogical culture and professional competence. Proc. of the V Internat. scient.-pract. conf., 2016 October 20-22; Baranovichi. Baranovichi: BarSU 2016:61-3.

12. Crutsevych TYu. Theory and methodology of physical education: textbook. Kyiv: Olympic literature; 2017. Vol. 2. Methodology of physical education of different population groups. $368 p$.

13. Luka K. Specifics of socialization of primary school children in extracurricular education institutions. In: Frolov M, editor. Moloda nauka 2015. Coll. of scient. papers of students, PhD students, and young scientists. 2015, April 7-9; Zaporizhzhia. Zaporizhzhia: Zaporizhia National University; 2015:329-330.

14. Mandel BR. Age-related psychology: study guide. Moscow: Textbook for higher education institutions: INFRA-M; 2015. 352 p.

15. Melekhov AV, Masliak IP. Physical fitness of primary school-age children. Actual issues of physical education, rehabilitation, sports and tourism. coll. of scient. papers. 2018:179-185 [Internet]. Retrieved from: http://journals.uran.ua/ hdafk-tmfv/article/view/167214.

16. Mikryukov VYu. Encyclopedia of Karate. 2018 [Internet]. Retrieved from: https://sport wikireading.ru/16677.

17. Moskalenko A, Dorofieieva T. Improving the level of physical fitness in primary schoo children through a comprehensive sports and game-based organization of physical education classes. Problemy i perspektyvy rozvytku sporty-

vnykh ihor i yedynoborstv u vyshchykh navchaInykh zakladakh. 2018;2:48-54.

18. Moskalenko NV. Physical education of primary school students: monograph. 3rd ed., rev. and suppl. Dnipropetrovsk: Innovatsiia; 2014. 375 p.

19. Petrovska T, Imas Ye, Serhienko V. Model of extracurricular practicing karate aimed at psychophysical and social development of junior school age children. Theory and methods of physical education and sports. 2018:2:83-8. https://doi.org/10.32652/tmfvs.2018.2.83-88

20. Popova AA. Success as an outcome of socialization of a student in karate. The role of innovations in the transformation of modern science. Coll. of papers of Internat. scient.-pract. conf. 2016, June 01; Ufa. Ufa; 2016:274-6.

21. Prysiazhniuk SI, Oleniev DG. Course of lectures on physical education [Internet]. Retrieved from: https://pidru4niki.com/92480/pedagogika/ biologichni osnovi fizichnogo rozvitku organizmu_lyudini.

22. Saienko VG, Skliar MS. Positive effects of karate training on children. 2012 [Internet] Retrieved from: https://www.researchgate.net/ publication/311536397.

23. Serhienko V. Evolutionary progress of specially organized extracurricular motor activity as a special kind of comprehensive development of younger schoolchildren. Sport science of Ukraine. 2018;2(84):36-9.

24. Chovgan RYa. Development of social activity of 10-11-year-old school children by means of physical culture in the settings of children's health-enhancing camp [avtoreferat] Ivano-Frankivsk: Vasyl Stefanyk Precarpathian National University; 2016. 18 p.

25. Geisler TM. Examining The Socialization Of Physical Education Teachers: A Case Study 2017. $725 p$

Надійшла 03.09.2021

\section{ІНФОРМАЦІЯ ПРО АВТОРІВ}

Петровська Тетяна Валентинівна petrovska.tetiana@gmail.com, https://orcid.org/0000-00033936-1965

Національний університет фізичного виховання і спорту України 03150, Київ, вул. Фізкультури, 1

Сергієнко Віталій Петрович elitsport@bigmir.net, https://orcid.org/0000-0003-4154-8702

Дитячо-юнацька спортивна школа «Сузір'я»

м. Київ, вул. Андрія Малишко 15/1

Красницька Ольга Володимирівна 0lya271272@ukr.net, https://orcid.org/0000-0002-04173318

Національний університет оборони України імені Івана Черняховського

03049, м. Київ, пр-т Повітрофллотський, 28

\section{INFORMATION ABOUT THE AUTHORS}

PetrovskaTetiana petrovska.tetiana@gmail.com, https://orcid.org/0000-0003-3936-1965

National University of Ukraine on Physical Education and Sport

03150, Kyiv, Fizkul'tury str.,

Sergiyenko Vitaliy elitsport@bigmir.net, https://orcid.org/0000-0003-4154-8702

Andriy Malyshko str. 15/1

Coach teacher

Krasnytska Olha Olya271272@ukr.net, https://orcid.org/0000-0002-0417-3318

National Defense University of Ukraine named after Ivan Cherniakhovskyi

Kyiv, Povitroflotskyi Avenue, 28 